\title{
Usage of Specialized Service Delivery: Evidence from Contiguous Counties*
}

\author{
Christopher B. Goodman ${ }^{\dagger} \quad$ University of Nebraska at Omaha
}

This study exploits exogenous policy discontinuities along state borders to estimate the influence of differences in local autonomy on the usage of special districts in U.S. counties. Using forty years of data, this analysis compares counties on either side of state borders where local autonomy differs and finds little to no evidence that negative changes in local autonomy leads to increased utilization of special districts. This study suggests that some prior literature may overstate the importance of local autonomy in local service delivery.

Keywords: special districts; local government; TELs; home rule; local autonomy

\section{Introduction}

Special districts are the most numerous form of local government in the United States. Even with this popularity, homeowners and voters are often ignorant of the special districts that provide services to them. Special districts typically provide a single service over a geographic area that can vary from a few parcels to an entire metropolitan area. Specialized service delivery and immense territorial flexibility enable diverse citizen demands to be met (Bollens 1986); however, the proliferation of special districts create a fragmented metropolis. Much of the recent literature on special district formation or reliance focuses on the role of changes in the autonomy of general purpose governments as important correlates of special district usage or creation (Farmer 2010; Carr and Farmer 2011; Bauroth 2015; Shi 2017; Goodman and Leland 2017). Theoretically, when general purpose governments are limited by the state in their ability to provide or finance public services, they tend to create special districts as a means continue to provide public services.

As Bowman (2017) explains, "[f]riction often characterizes the relationship of local jurisdictions to their states." Local governments depend on having sufficient autonomy to be responsive to their citizens. However, state governments determine the appropriate level of local autonomy. This friction as Bowman calls it is likely the result of two countervailing forces: rising state centralization (Bowman and Kearney 2011) and local governments' desire to be responsive to citizen demands with their myriad constraints. These forces fall under the guise of "second-order" devolution and play out directly in the analysis to follow. Do reductions of local authority by states lead local governments to be responsive to their citizens in other ways? Increased special district reliance is one potential means to answer this question in the affirmative. The empirical evidence of this question is mixed. The movement of service delivery from general purpose local governments

${ }^{*}$ I thank the editor and the four anonymous referees for improving the content and exposition of this paper. I further thank the North Carolina State University's School of Public and International Affairs Visiting Scholars Program for the invaluable comments.

${ }^{\dagger}$ cgoodmaneunomaha. edu 
to other local actors including special districts is inherently an issue of "Third Order Devolution" (TOD) and is currently unexplored in the literature (Bowman and Kearney 2011).

Studies of special district formation and special district reliance tend to focus on the number of new or existing special district in a geographic area as their unit of analysis. As Foster (1997) explains, these studies are susceptible to bias in their enumeration of special districts because the most popular dataset for such analyses, the Census of Governments, has a limited definition of a special district. Foster suggests there is utility in examining alternate measures of special district reliance that does not utilize counts of districts and examining whether the prior empirical findings still hold. Following Foster, this study envisions special district reliance as the special district share of local public spending.

Additionally, local government autonomy is often a slow changing concept. Once a form of government is granted (or denied) certain powers, that tends to be the state of local autonomy for such governments for some time. ${ }^{1}$ This presents challenges in researching local autonomy as there is often not enough within or cross state variation in defined measures of local autonomy to estimate effects. Following Dube, Lester, and Reich (2010), this paper exploits policy discontinuities along state borders to identify the effect of local autonomy, using only the variation in local autonomy within each county border-pair. A model is specified comparing all contiguous county-pairs in the United States that are located on opposite sides of state borders. This is a marked departure from the prior literature that relies on unit and period fixed effects and is an improvement in the ability to identify the effects of local autonomy on special district reliance.

The results of this analysis suggest little systematic relationship between grants or denials of local autonomy and the usage of special districts. The only consistent finding is a negative relationship between municipal debt limits and special district reliance on the order of magnitude of 3 to 3.75 percent. This is similar to the point estimates of Nelson (1990), Carr (2006), and Farmer (2010); however, none of their findings are statistically distinguishable from zero. This largely null finding is consistent with some of the local autonomy literature (Berry 2009; Billings and Carroll 2012; Lewis 2000; Shi 2017); however, the empirical approach presented here is a significant departure from prior literature and allows for triangulation of results. This analysis provides weight to prior null findings about the relationship between local autonomy and special district reliance.

The analysis proceeds as follows. First, the previous literature on special districts in the United States is examined. Special attention is paid to historical trends, attributes that make special districts unique in the U.S. local government system, and influences on the creation and usage of such districts. Next, the data and empirical model exploiting policy discontinuities along state borders is explained. Results are presented and the implications for future research are explored.

\section{Previous Research}

\section{Special Districts in the United States}

Special districts are the most popular form of local government in the United States. According to the Census of Governments, there were 38,266 special districts in 2012 (U.S. Census Bureau 2013) accounting for more than 40 percent of all local governments (Maynard 2013). This is roughly

\footnotetext{
${ }^{1}$ This assertion is ultimately an empirical question that has yet to be examined in the literature. This notwithstanding, I make no claims of causality about the persistence of grants of local autonomy but use this assertion as a motivation to explore alternate empirical methods.
} 
twelve times larger than the number of counties and twice as large as the number of municipalities or towns/townships. Additionally, the growth over time in the number of special districts has been much higher than other forms of local government. Since 1952, the growth in the number of special districts was 210 percent with an annualized growth rate of 1.9 percent. This is much larger than the growth in general purpose local governments over the same time period (5.5 percent; annualized growth of 0.09 percent). The growth in new special districts has slowed somewhat in recent years (since 2000), but shows little signs of abating.

The data on special districts utilized in this study and is the most commonly used data in the literature is from the Census of Governments. The U.S. Census Bureau defines a special district as governments that "are independent, special purpose governmental units that exist as separate entities with substantial administrative and fiscal independence from general purpose local governments" (U.S. Census Bureau 2013). ${ }^{2}$ They key characteristics are administrative and fiscal independence. Fiscal independence is achieved through the power to determine a budget, levy taxes, charge user fees, or issue debt without review for another governmental entity. Administrative independence is achieved through fiscal independence plus having 1) an independently elected governing body, 2) a governing body representing two or more state or local governments, or 3) an appointed board with functions different from the appointing government. This definition excludes entities when fiscal or administrative independence is violated. Typically, administrative independence is violated though the composition of the governing body. In these cases, the entity is classified as "dependent" and its financial and employment data is added to the sponsoring government's information. Even with this limited definition, the Census of Governments data provide the best and most comprehensive data on special district activities in the United States.

An important unique characteristic of special districts is their territorial flexibility (Bollens 1957). Unlike cities or some towns, special districts may take on nearly any shape and may overlap other forms of local government including other special districts. This allows special districts to take on near infinite spatial arrangements. Additionally, territorial flexibility allows the collection of special districts serving any particular area to change rapidly over short distances. Two parcels located next to each other may enjoy vastly different public services at differing costs solely because of their inclusion (or exclusion) from various special districts. Special districts are also often free from many legal restrictions imposed on general purpose local governments. ${ }^{3}$ Special districts can typically be created to cover any land area without consideration to assessed value, population, or territorial size (Bollens 1957). Special district elections are exempt from the one person/one vote requirement (Briffault 1993; Burns 1994). ${ }^{4}$ As a result, voting rights can be apportioned on the basis of any number of bases with owning property within the district being particularly popular. Burns (1994) argues that special districts appear to go out of their way to limit political participation and participation in special district elections is low (Hudson 1996; Little Hoover Commission 2000). This is a marked difference from general purpose governments even though turnout in local government elections tends to be quite low (See Bauroth (2005) for a richer discussion on the uniqueness of special district elections).

\footnotetext{
${ }^{2}$ This definition applies to independent school districts as well, but the Census Bureau accounts for these districts differently as they are more visible in the local community.

${ }^{3}$ Cities and towns/townships.

${ }^{4}$ Salyer Land Co v. Tulare Basin Water Storage District, 410 U.S. 719 (1973) and Ball v. James, 451 U.S. 355 (1981).
} 


\section{Local Autonomy \& Special Districts}

The most predominant view on why special districts are created and how local autonomy interacts with it comes from a political economy approach (Tiebout 1956; Burns 1994). Under the political economy approach, local governments are created to access the powers associated with those forms on government. Burns (1994) suggests that general purpose local governments are largely created to access the power to exclude individuals from a community, typically via zoning ordinances. Special districts are often created to access the power to provide public services.

A separate literature associated with Burns (1994) relates the granting or denial of powers of general purpose local governments to the creation of usage of special districts (Carr 2006; Carr and Farmer 2011; Farmer 2010; Foster 1997; McCabe 2000; Shi 2017). When general purpose local governments are limited in their ability to provide public services, they may turn to special districts to circumvent the limitations (Bunch 1991; Sbragia 1996). An implicit assumption of this literature is that voters and businesses are agnostic to who provides public services. If a general purpose local government cannot satisfy their demands, a special district is suitable substitute.

In general, the literature on local autonomy utilizes a typology developed by the now defunct Advisory Commission on Intergovernmental Relations (1981). The ACIR defines local discretionary autonomy as a four dimensional concept: structural, functional, finance, and personnel (sometimes known as administrative). Structural autonomy generally pertains to the ability of local governments to determine their governmental form. Functional autonomy typically pertains to the ability of local governments to determine which services they must deliver and which are optional. Fiscal autonomy tends to take the form of tax and expenditures limitations, but can also pertain to limitations on debt. Personnel or administrative autonomy generally pertains to rules surrounding local government employees such as collective bargaining, pensions, and required training.

Of the four types of local autonomy and their connection to the creation/usage of special districts, fiscal autonomy is the most studied. MacManus (1981) is among the first to find a positive correlation between property tax and borrowing limitations and the usage of property taxing special districts. This positive association between TELs and other forms of fiscal restrictions has been found in the literature many times since in many different forms. McCabe (2000) finds a positive relationship between TELs and special district creation at the state level. Nelson (1990) finds a similar effect at the metropolitan level. Bowler and Donovan (2004), Carr (2006), Carr and Farmer (2011), and Goodman and Leland (2017) all find a positive relationship between TELs and special districts contingent on some other influence. ${ }^{5}$ Even with these positive correlations, there are numerous negative (Bauroth 2015; Foster 1997) and null findings (Berry 2009; Billings and Carroll 2012; Lewis 2000; Shi 2017) in the literature.

Other forms of local autonomy are much less studied in the literature. The trend in these findings is generally toward a null effect; however, there are some standouts. McCabe (2000) finds that various restrictions on and grants of autonomy of the structural form can lead to the opposite of circumvention (i.e fewer special districts created). Limits on annexation have a positive correlation with special district creation while grants of autonomy to counties have a negative effect. The underlying idea being that when a local government is restricted (or empowered) somehow, they rely on special districts more (less). Nelson (1990) finds the opposite result to McCabe (2000) where grants of structural home rule are positively associated with special district usage.

\footnotetext{
${ }^{5}$ Ease of use of direct democracy for Bowler and Donovan (2004), city TELs contingent on county TELs for Carr (2006) and Carr and Farmer (2011), and city TELs contingent on functional autonomy for Goodman and Leland (2017).
} 


\section{Gaps in the Current Literature}

Nearly all the preceding literature examines the usage of special districts from perspective of the number of said districts in a geographic area (either the total or newly created). This approach is valid, but the connection between special districts and actual service delivery is not one-to-one. As Foster (1997) explains, there are many pitfalls with using the count of special districts an area to equate the importance of special districts in that area. There are many special districts that exist on paper; however, they have no employees or expenditures. These districts are not providing public services, but would count as contributors to service delivery in a count-based measure. Additionally, using counts to equate importance ignores the potential for "excess capacity" among existing special districts (Foster 1997). Many special districts could accommodate an increase in service delivery without the need to create additional districts. Under a count-based model, special districts would be seen as no more important when they have increased their service provision and importance in the local public economy. To alleviate these problems, Foster (1997) suggests focusing on measures of special district utilization that focuses on functional breadth (e.g. what services areas special districts being used for) and financial significance. ${ }^{6}$

Additionally, virtually all the literature on local autonomy and its relationship with special districts relies on an identification strategy that is ill suited to estimate the impact of local autonomy. Within-state changes in local autonomy are rare making a traditional state- or county-fixed effects model difficult to estimate. A better experiment can be constructed. I present more on this argument in the sample construction section; however, in this analysis, I take the approach of exploiting state borders as a source of exogenous policy discontinuities. By comparing counties on either side of the discontinuity, a better experiment is constructed. The next section continues to examine the gaps in the literature and proposes solutions for these gaps by altering the traditional estimation technique for these types of analyses.

Aside from the more technical issues of this analysis, there is a distinct gap in the literature surrounding how special districts fit into what Bowman and Kearney (2011) call "third-order" devolution. Second-order devolution involves state to local (or lack thereof) transfers of authority. The analysis as presented here involves how second-order devolution (state changes in local autonomy) may ultimately lead to third-order devolution, where general purpose local governments create special districts to "alleviate local service deficiencies" (Bowman and Kearney 2011). The literature has yet to explore many issues surrounding third-order devolution and this analysis can be viewed as an initial step.

\section{Data Sources \& Sample Construction}

\section{Data Sources}

A constant source of complaint in the literature above is with the quality of data from the Census Bureau (Leigland 1990b, 1990a; Sacks 1990; Foster 1997). There are two primary concerns with the Census of Governments special districts data. First, the Census Bureau likely undercounts the number of special districts through their requirements for administrative and fiscal independence.

\footnotetext{
${ }^{6}$ This study ultimately focuses on the latter. This is largely due to concerns of endogeneity where local functional autonomy predetermines that a particular functional area is the exclusive domain of special districts on one side of a border and not on the other. Functional breadth is important; however, in the context of this study, the potential bias introduced via endogeneity is too high of a cost.
} 
This strict definition eliminates districts that many states would consider to be active special districts (Leigland 1990b). Second, the Census Bureau also likely over-counts the number of special districts by counting special districts that have no revenues or expenditures, no employees, and no outstanding debt. An additional concern is districts that have ceased providing services and are in the process of being closed out (i.e. collecting revenue to clear debts). Functionally, these districts are not active in service provision and therefore should not be counted. Additionally, Foster (1997) cautions against equating counts of special districts with the importance of special districts in any particular area (see above). This idea is closely aligned with the second concern where many districts exist, but do very little from a service delivery perspective. These issues not withstanding; the clear majority of the literature on special districts utilizes the Census of Governments data on special districts and often little is done to minimize any of these issues.

Attempting to mitigate these criticisms is a current gap in the literature. This analysis strives to resolve the second data issue, over-counting, and Foster's concern of equating counts to importance by focusing on special district spending rather than counts of special districts. By doing so, non-active special districts will not be captured and will likely portray a more accurate view of the importance of special districts in local public economies (Foster 1997). The first problem, undercounting, is not dealt with in this analysis. Devising a method of adding uncounted special districts, particularly on a historical basis, is beyond the scope of this research and may ultimately be impossible. Therefore, this should be considered an initial attempt to eliminate the some of the complaints in the literature. ${ }^{7}$

To construct the dependent variable, individual level data on all local governments from the Census of Governments is utilized. Direct expenditures for all special districts and all local governments in a county is tabulated. The ratio of these two measures of spending forms the dependent variable. As such, it measures special district utilization as a function of the proportion of local spending expended by special districts. ${ }^{8}$ The typical dependent variable in analyses of the effects of local autonomy is the number of new or existing special districts in a local area. The dependent variable presented here is not dependent on the creation of additional special districts to detect an influence of changes in local autonomy. Existing special districts with "excess capacity" can increase their importance in local service delivery independent of creating new governments. This dependent variable resolves the over-counting issue inherent in the Census of Governments data and broadens the definition of special district utilization.

Data on local autonomy is largely sourced from the now-defunct Advisory Commission on Intergovernmental Relations (ACIR). ${ }^{9}$ The measurement of tax and expenditures limitations draws heavily on the work of Advisory Commission on Intergovernmental Relations (1995) and expanded upon by Joyce and Mullins (1991), Mullins and Joyce (1996), and Mullins and Wallin (2004). As explained in Mullins and Wallin (2004), TELs come in seven varieties: 1) overall property tax rate limits applied to all governments, 2) specific property tax rate limits only applied to certain forms of government, 3) property tax levy limits, 4) general revenue increase limits, 5) general expenditure increase limits, 6) limits on assessment increases, and 7) truth in taxation requirements. These specific limitations can be grouped together by the extent to which they bind

\footnotetext{
${ }^{7}$ It should be noted that Foster (1997) utilizes a very similar conceptualization in one of the chapters of her book.

${ }^{8}$ Direct expenditures are chosen rather than revenues to focus the analysis on service provision.

${ }^{9} \mathrm{~A}$ persistent issue with ACIR data surrounding local discretion is a lack of nuance related to local governments of the same form within individual states (Carr 2006). This is an issue for understanding local autonomy generally, but does not pose an issue here given the estimation technique. However, it does limit the ability to draw conclusions about individual cities without ecological fallacy problems.
} 
the behavior of the restricted government. A potentially binding TEL is composed of any of the following specific limits or a combination of two limits: an overall or specific rate limit combined with an assessment limit, a property tax levy limit, a general revenue or general expenditure limit. This definition forms the basis of the TEL variable and can be imposed on city or counties governments independently. The data from Mullins and Wallin (2004) is current up to the early 2000s. I have continued to update to this dataset, largely via the Lincoln Institute for Land Policy's Significant Features of the Property Tax data. ${ }^{10}$

Data on local debt limits comes from Advisory Commission on Intergovernmental Relations (1993). Unfortunately, these data are only valid up to 1990. I have updated these data to reflect any changes in constitutional or statutory debt limits since. This involved a comprehensive examination of the debt limitation legal citations in ACIR (1993) via Westlaw to determine if a previously reported debt limit was still operative, changed, or new provisions added. These data including updated legal citations are available upon request. The presence of a debt limit is indicated if a state imposes a limitation of a city or county's total level of bonded debt as a function of assessed value or millage rate. This measure is chosen over other alternatives because it provides a concrete limitation on local government behavior. Finally, functional autonomy data comes from Krane, Rigos, and Hill (2001). Functional autonomy is defined as the ability of a general purpose local government to choose the services they wish to provide. The presence of functional autonomy for cities or counties is indicated if a state grants local governments the power to exercise local self government (i.e. choose the services they wish to provide) in a broad or limited manner.

\section{Sample Construction}

This analysis utilizes a number of samples. First, a panel of all counties in the contiguous United States is utilized. Second, a sample of all urban counties in the contiguous United States is utilized. I define urban as being a member of a metropolitan statistical area using OMB's 1999 definition. Contiguous border counties form the third and fourth samples. These two samples are significantly more complex and their explanations will follow. The panel of all counties consists 3,070 counties with an unbalanced panel of 24,485 observations and is inclusive of all Census of Governments from 1972 to 2012. The Census of Governments is conducted in years ended in two and seven and the data presented here are inclusive of nine such censuses. The urban counties sample consists of 814 counties with an unbalanced panel of 6,472 observations.

Borrowing from Dube, Lester, and Reich (2010), the third and fourth samples consist of all contiguous county border pairs that straddle a state border. Of the 3,070 counties in the all counties panel, 1,158 lie along a state border. Among these 1,158 counties, there are 1,305 distinct pairs of counties. If the contiguous border sample is limited to only those MSAs that straddle at state border, the sample is further reduced. There are 35 primary metropolitan statistical areas that cross a state border using the 1999 definition. This results in a reduction to 132 counties and 102 unique border pairs. Figure 1 demonstrates all contiguous border pairs for the six different measures of local autonomy utilized in this study. A border county pair is shaded black if there is a difference along this border in one of the six measures of local autonomy at any point between 1972 and 2012. As such, Figure 1 demonstrates the specific borders where identification of the models below occurs. These border county samples utilize all applicable county pairs. As such, any individual

\footnotetext{
${ }^{10} \mathrm{http}: / /$ datatoolkits.lincolninst.edu/subcenters/significant-features-property-tax/
} 
county may appear more than once in the dataset dependent on how many counties across a state border it abuts.

Table 1 provides descriptive statistics for the four samples. The four samples are quite similar in their mean values of the dependent variable and local autonomy variables. Across the entire time period (1972-2012), special districts account for approximately 7.5 percent all local local spending on average. Generally, cities are subjected to fewer TELs, more debt limits, and higher levels of functional autonomy. Contrastingly, counties are subjected to higher levels of TELs, more debt limits, and lower levels of functional autonomy. These descriptive statistics suggest that states see cities as primary service providers who need some oversight in the debt realm. As creatures of the state, counties as a more limited service provider, but an important service provider in a few state-mandated areas. Naturally, the urban focused samples ( 2 and 4 ) are somewhat more wealthy, larger in terms of population, denser, have more jobs, and utilize special districts at a higher rate than the national samples.

Table 1: Descriptive statistics

\begin{tabular}{|c|c|c|c|c|c|c|c|c|}
\hline & \multicolumn{2}{|c|}{ (1) } & \multicolumn{2}{|c|}{ (2) } & \multicolumn{2}{|c|}{ (3) } & \multicolumn{2}{|c|}{$(4)$} \\
\hline & \multicolumn{2}{|c|}{ All county panel } & \multicolumn{2}{|c|}{ Urban county sample } & \multicolumn{2}{|c|}{$\begin{array}{l}\text { Contiguous border } \\
\text { county-pair sample }\end{array}$} & \multicolumn{2}{|c|}{$\begin{array}{c}\text { Contiguous border MSA } \\
\text { county-pair sample }\end{array}$} \\
\hline & Mean & St. Dev. & Mean & St. Dev. & Mean & St. Dev. & Mean & St. Dev. \\
\hline $\begin{array}{l}\text { Direct expenditures } \\
\text { (special district share) }\end{array}$ & 0.076 & 0.107 & 0.075 & 0.095 & 0.077 & 0.106 & 0.073 & 0.094 \\
\hline Mun. TEL & 0.558 & 0.497 & 0.538 & 0.499 & 0.520 & 0.500 & 0.503 & 0.500 \\
\hline Cnt. TEL & 0.573 & 0.495 & 0.574 & 0.495 & 0.539 & 0.499 & 0.532 & 0.499 \\
\hline Mun. debt limit & 0.874 & 0.332 & 0.840 & 0.367 & 0.850 & 0.357 & 0.849 & 0.358 \\
\hline Cnt. debt limit & 0.803 & 0.398 & 0.762 & 0.426 & 0.775 & 0.418 & 0.797 & 0.402 \\
\hline Mun. FHM & 0.743 & 0.437 & 0.747 & 0.435 & 0.677 & 0.468 & 0.741 & 0.438 \\
\hline Cnt. FHM & 0.439 & 0.496 & 0.435 & 0.496 & 0.425 & 0.494 & 0.458 & 0.498 \\
\hline Personal income, per capita & 23.659 & 8.212 & 27.038 & 8.920 & 23.767 & 8.609 & 27.150 & 9.170 \\
\hline Population (1000s) & 84.554 & 292.585 & 248.226 & 529.868 & 91.877 & 361.788 & 227.282 & 308.551 \\
\hline Population density & 0.175 & 0.883 & 0.531 & 1.609 & 0.236 & 1.720 & 0.758 & 1.719 \\
\hline Jobs, per capita & 0.355 & 0.138 & 0.398 & 0.137 & 0.359 & 0.131 & 0.399 & 0.152 \\
\hline Age index & 0.430 & 0.031 & 0.409 & 0.027 & 0.431 & 0.029 & 0.408 & 0.028 \\
\hline Race index & 0.124 & 0.146 & 0.151 & 0.130 & 0.126 & 0.157 & 0.160 & 0.151 \\
\hline No. of special districts & 10.596 & 16.851 & 17.523 & 27.294 & 11.437 & 15.684 & 13.578 & 18.059 \\
\hline Use of towns (Yes=1) & 0.314 & 0.464 & 0.354 & 0.478 & 0.300 & 0.458 & 0.304 & 0.460 \\
\hline Chg. In cities & 0.039 & 0.378 & 0.099 & 0.611 & 0.038 & 0.423 & 0.104 & 0.998 \\
\hline No. of counties & 3,070 & & 814 & & 1,143 & & 132 & \\
\hline No. of county-pairs & NA & & NA & & 1,254 & & 102 & \\
\hline No. of states & 48 & & 47 & & 48 & & 32 & \\
\hline
\end{tabular}

\section{Contiguous Border Counties as Controls}

Contiguous border counties likely provide a better test of the influence of local autonomy on special district utilization than states or counties with unit and time fixed effects. This is for two primary, yet interconnected, reasons. First, contiguous border counties are likely relatively similar in their underlying need and/or demand for specialized service delivery. The geographic and population characteristics of counties on either side of a quasi-arbitrary state border are likely to be highly similar. Therefore, border counties are an improvement in controls over any other randomly selected county which would be the case for a traditional model with unit and time fixed effects. The similarity in underlying conditions makes differences along state borders act like a quasi-experiment. If the underlying conditions are the same, any differences in the utilization of special districts across the border can be attributed to differences in state policy, all else equal. 


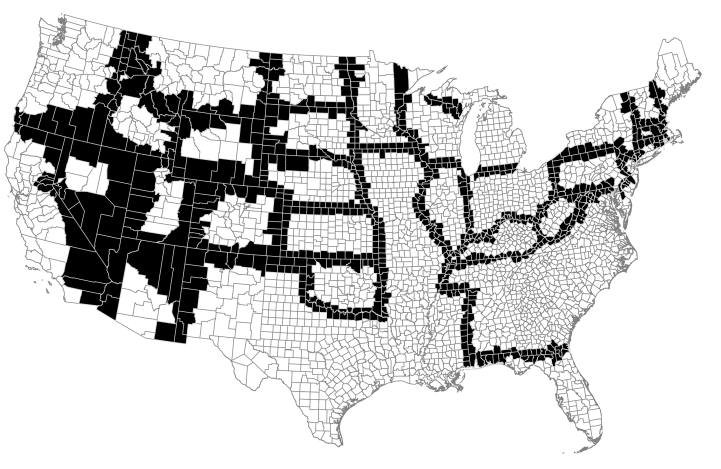

(a) City TEL

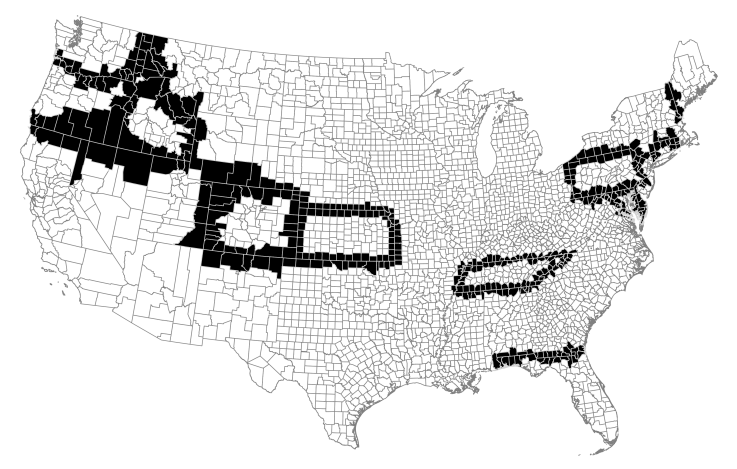

(c) City debt limit

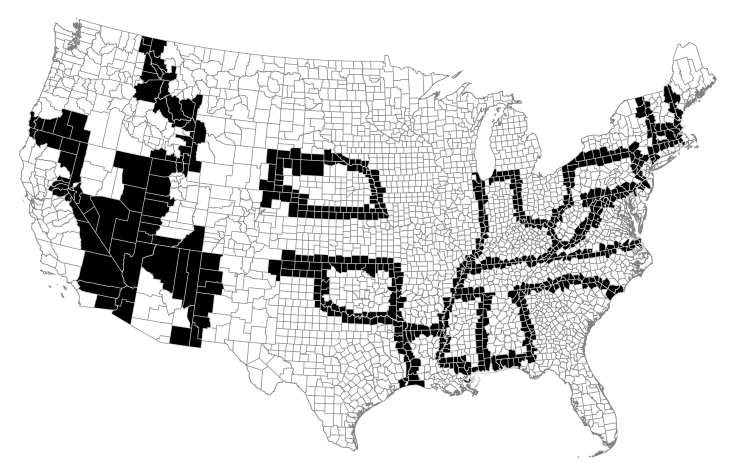

(e) City home rule

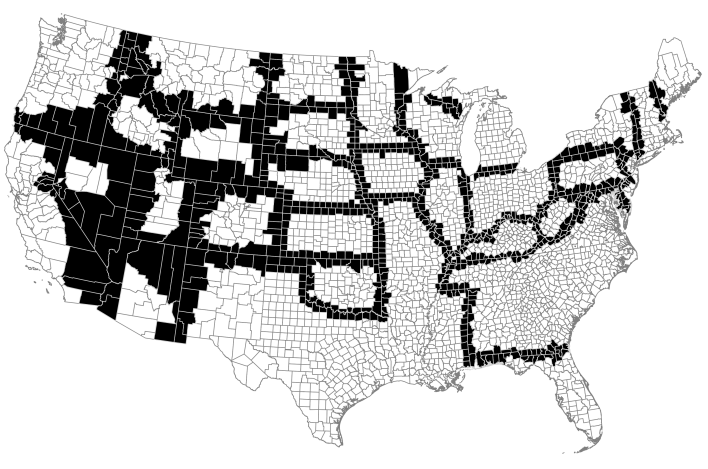

(b) County TEL

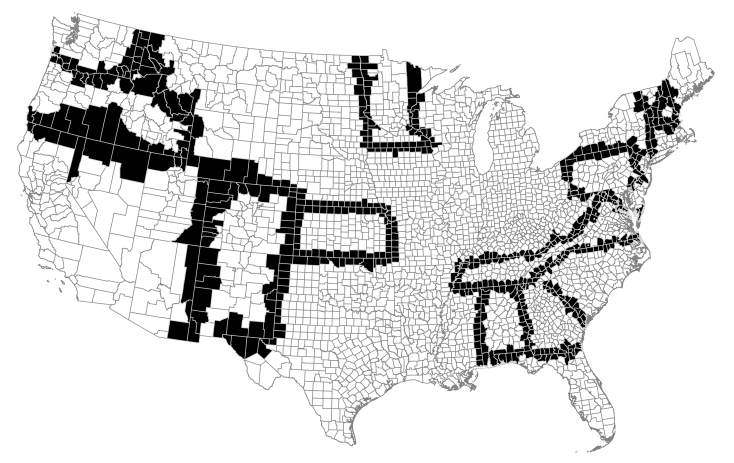

(d) County debt limit

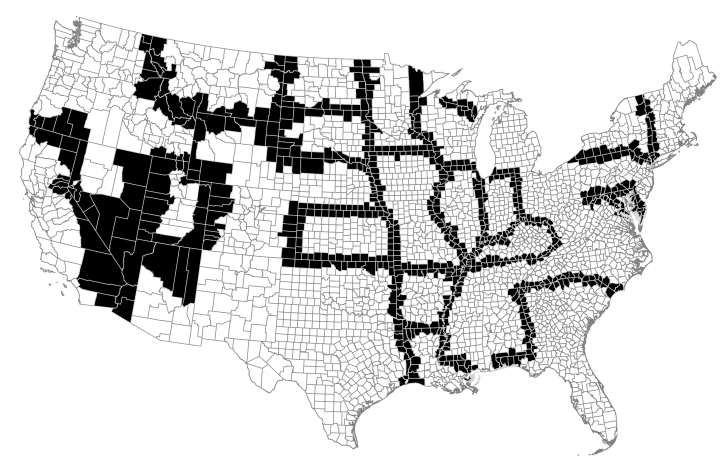

(f) County home rule

Figure 1: Contiguous border county-pairs with a difference, 1972-2012 
To demonstrate this point, a simple falsification test is employed. For counties in the period just prior to their states' adoption of either a county or municipal TEL, the mean absolute deviation ${ }^{11}$ is calculated for county border pairs and counties matched to a random county (also unaffected by a TEL). If border county pairs are a better control group, the difference between border counties should be smaller, all things equal, prior to the intervention. For both forms of TEL, the border pair group has a smaller difference prior to the introduction of a TEL ( 0.080 for a municipal TEL and 0.081 for county TEL) than a "treated" county compared to a random county ( 0.081 for a municipal TEL and 0.085 for county TEL). The difference is small, but demonstrates that county border pairs are closer to pure random assignment than comparing random counties without regard for geography. The combination of these two factors is a fundamentally stronger empirical test of the relationship between local autonomy and special district utilization than has been attempted in the literature.

\section{Empirical Strategy}

\section{All Counties Sample}

To provide a baseline "traditional" approach, something similar to what is typical in the local autonomy literature, I first estimate a model examining changes in special district utilization as a function local autonomy using the all counties sample, including county and year fixed effects. This specification typical of that found in the extant literature and is most similar to that of Goodman and Leland (2017).

$$
\text { share }_{i t}=\alpha+\delta \boldsymbol{M}_{i t}+\rho \boldsymbol{C}_{i t}+\beta \boldsymbol{X}_{i t}+\phi_{i}+\tau_{t}+\varepsilon_{i t}
$$

Equation 1 has the share of special district spending as a function of local autonomy for municipalities $\left(\boldsymbol{M}_{i t}\right)$, local autonomy for counties $\left(\boldsymbol{C}_{i t}\right)$, and a vector of control variables $\left(\boldsymbol{X}_{i t}\right)$. Importantly, county $\left(\phi_{i}\right)$ and year $\left(\tau_{t}\right)$ fixed effects are included. Therefore, identification comes from within county changes over time. Additionally, county areas are compared to each other and all counties share a common time effect. Equation 2 introduces MSA-specific time effects $\left(\tau_{m t}\right)$ which limits the sample of data to only urban counties.

$$
\text { share }_{i t}=\alpha+\delta \boldsymbol{M}_{i t}+\rho \boldsymbol{C}_{i t}+\beta \boldsymbol{X}_{i t}+\phi_{i}+\tau_{m t}+\varepsilon_{i t}
$$

The overall specification is the same as equation 1; however, the introduction of MSA-specific time effects $\left(\tau_{m t}\right)$ eliminates the variation between MSAs and identifies $\delta$ and $\rho$ based on variation within individual MSAs. Since local autonomy is measured at the state level, identification of equation 2 is predicated on MSAs that cross state lines. There are 35 such MSAs in 1999.

Taken together, equation 1 and 2 form the baseline estimate of the influence of local autonomy on special district usage. The results from these estimates will provide a baseline to compare the results of the contiguous border county-pair results.

\section{Contiguous Border County-Pair Sample}

The preferred specification of this analysis is to exploit state borders as a source of exogenous policy variation. Doing so requires changing the sample from that utilized above. Equations 3 and

\footnotetext{
${ }^{11}$ This is calculated as $M A D=\frac{1}{n} \sum_{i=1}^{n} \mid$ count $_{1 j}-$ county $_{i j} \mid$.
} 
4 utilize the continuous border county-pairs sample. Equation 3 is specified similar to equation 1; however, the specification explicitly allows for counties to be repeated in the data for each pair they are a part of, denoted as share $i_{i p t}$ and $\varepsilon_{i p t}$. Additionally, border county pair-specific time fixed effects are included $\left(\tau_{p t}\right)$. By doing so, equation 3 utilizes only the variation within each countyborder pair. This essentially constructs a spatial difference in difference model. As such, only the variation in local autonomy across state borders for any period if used to identify equation 3.

$$
\text { share }_{i p t}=\alpha+\delta \boldsymbol{M}_{i t}+\rho \boldsymbol{C}_{i t}+\beta \boldsymbol{X}_{i t}+\phi_{i}+\tau_{p t}+\varepsilon_{i p t}
$$

Finally, the most restrictive specification, equation 4 includes MSA-specific county-pair fixed effects $\left(\tau_{m p t}\right)$ restricting the sample to those border counties that are included in a MSA in 1999. This is similar that the specification in equation 2, but only utilizes those counties that lay on opposite sides of a state border. This reduces the number of states to 32.

$$
\text { share }_{i p t}=\alpha+\delta \boldsymbol{M}_{i t}+\rho \boldsymbol{C}_{i t}+\beta \boldsymbol{X}_{i t}+\phi_{i}+\tau_{m p t}+\varepsilon_{i p t}
$$

The construction of the samples and specifications likely bias normally calculated standard errors. Following Dube, Lester, and Reich (2010), the following adjustments are made. First, for equations 1 and 2, standard errors are clustered on the state. This is to adjust the downward bias in standard errors as the result of serial autocorrelation in the share of special district spending and local autonomy being constant within each state. Second, for equations 3 and 4 , standard errors are clustered on both the state and the border segment. ${ }^{12}$ The inclusion of a county in multiple border-pairs introduces a correlation between border-pairs. As Dube, Lester, and Reich (2010) explains, this results in a correlation between the residuals of counties in the same state or along the same border. The multiway clustering explained above effectively controls for this correlation, local autonomy being constant within each state, and serial autocorrelation.

\section{Results}

Table 2 reports the findings for four equations specified above. For models two through four, specifications have been displayed that include the equations with and without their respective unit $\times$ year fixed effects to demonstrate the effect of limiting the variation to only that within such aggregations.

All four specifications demonstrate different effects of local autonomy on the usage of special district governments. The most "traditional" specification, (1), demonstrates only a negative effect of municipal debt limits. All other forms of local autonomy included are statistically insignificant. Unfortunately, I am unable to directly compare these results to a similarly specified model found in the literature as a dependent variable such as this is not currently used. However, I can compare these results to those models that utilize the count of special district as their dependent variable. A null finding for the relationship between TELs and special district usage is supported by Berry (2009), Billings and Carroll (2012) and Shi (2017). Null findings for debt limits and functional home rule are supported by Carr (2006) and Shi (2017). Carr (2006) has the most comprehensive model related to local autonomy and finds limited support that local autonomy influences special district usage at the state level. As a baseline, model 1 presented here does a fair job of replicating that finding. Limiting the baseline model to only urban counties does little to change the results.

\footnotetext{
${ }^{12} \mathrm{~A}$ border segment is all counties that fall along a border between two states.
} 


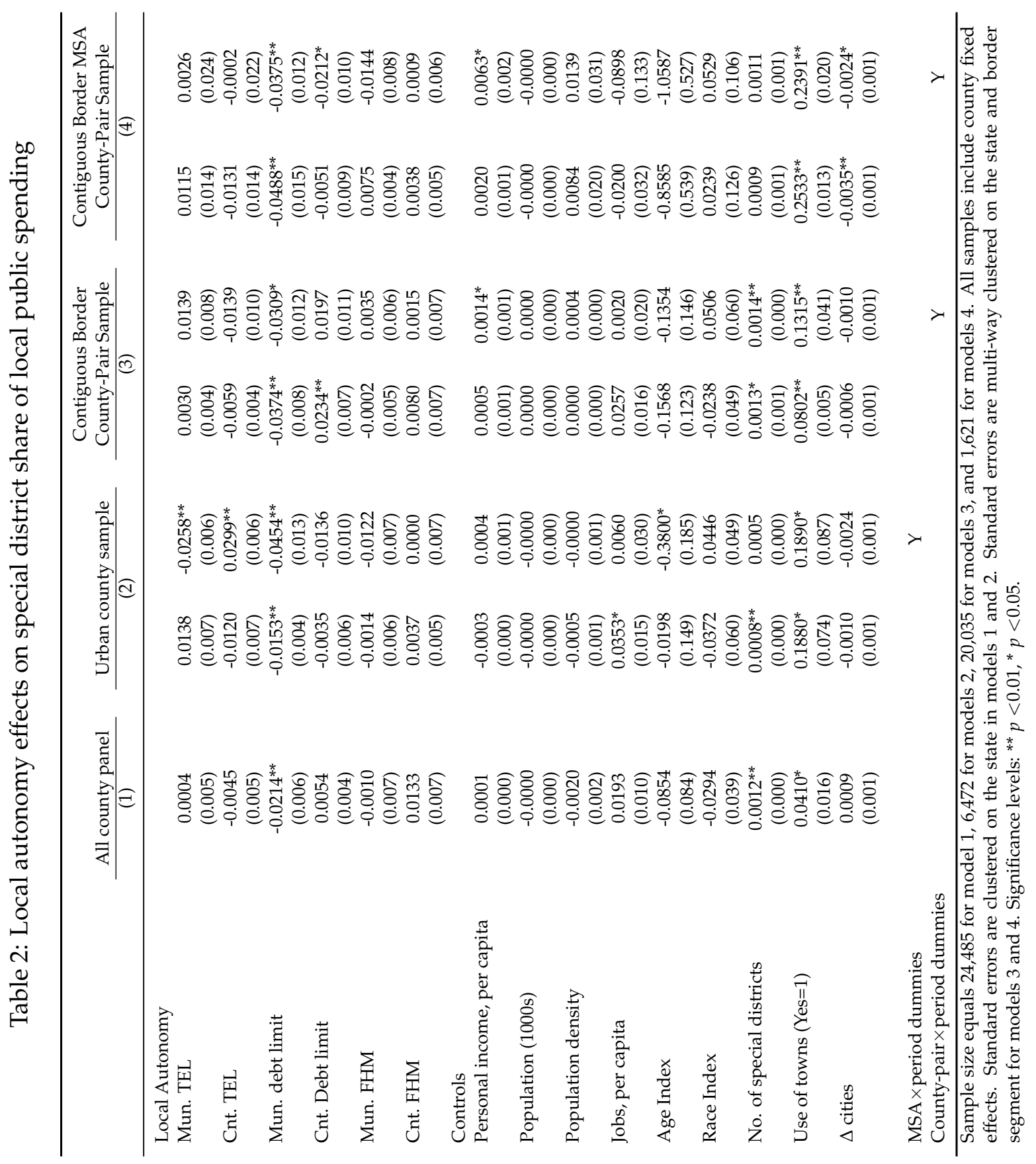


Municipal debt limits are the only measure of local autonomy that is statistically significant and the effect is roughly half that of the baseline model (1). Introducing MSA $\times$ year fixed effects, limiting the variation to only intra-MSA, reveals an effect of municipal and county TELs on the share of special district spending. Having a municipal TEL decreases special district usage by approximately 2.5 percent, all else equal. This result is qualitatively similar to Foster (1997). The negative sign is explained as a TEL signaling to city governments an overall negative taxing and spending environment and may lead them to respond by being more conservative. There is an almost exactly opposite relationship for having a county TEL with an increase in usage of approximately 3 percent on average. The negative effect of having a municipal debt limit is preserved from prior models; however, the effect size is roughly double what it was previously.

Moving to the preferred specification in models (3) and (4), one can see that the negative influence of municipal debt limits on the share of special district spending is preserved, even after using a more appropriate control group and policy discontinuities. Regardless of whether the sample is of all border counties or just those in MSAs, the effect size is slightly smaller than that of model (2) with MSA $\times$ year fixed effects. With this more rigorous specification, this finding is surprising as it has no support from the relevant literature. All prior literature finds either no effect of debt limits on special district utilization (Shi 2017; Frant 1997; Carr 2006) or a positive effect (Bunch 1991; MacManus 1981; McCabe 2000; Foster 1997). However, examining what the intended effect of debt limits on general purpose governments is may provide a route to explain these unusual results. Following Yusef et al. (2013), debt limits on cities and counties should affect two areas of debt financing: borrowing scale and borrowing cost. Most obviously, limiting the amount of debt a general purpose government may accumulate imposes a restriction on debt issuance (i.e. scale). This reduction in scale should reduce the overall amount of debt service payments required and leave more funds available to be spent, all else equal. Debt limits should also reduce borrowing costs by imposing fiscal discipline on local governments. This increase in discipline should reduce borrowing costs by lowering the default risk of debt issuances, thereby increasing credit rating. The result is the same as for reductions in borrowing scale: lower debt service payments required and more funds available to be spent elsewhere. Yusef et al. (2013) suggest that the evidence that debt limits decrease borrowing costs is thin. However, debt limits have been shown to decrease borrowing scale (Pogue 1970; McEachern 1978; Farnham 1985).

If the theoretical model proposed by Yusef et al. (2013) is correct, municipal debt limits may increase available funds for cities, negating the need to rely on special districts. This is not generally how the recent literature views the relationship between debt limits and special districts. Faulk and Killian (2017) examine the linkage between special districts and debt and conceptualize their analysis through a circumvention argument similar to Sbragia (1996). They find evidence that an increase in the number of special districts is associated with more aggregate local government debt in five states. This finding is suggestive that general purpose local governments are circumventing debt limits by shifting debt to special districts. However, the key linkage between debt limits and special districts is not empirically explored. The findings from this analysis would suggest just the opposite. Debt limits may induce the creation of new special districts, but it appears those limits reduce the importance of special districts in service delivery. The exact relationship between debt limits and aggregate debt is ultimately outside of the scope of analysis; however, this discussion about how a debt limit may interact with multiple limited and unlimited governments provides some context to an odd finding that is not generally found in the extant literature. 
The remaining results from model (3) suggest a positive relationship between many local autonomy variables and district utilization; however, other than municipal debt limits discussed above, none achieve statistical significance. The results for the preferred specification of model (4) are more inconsistent with a few variables changing signs, but again, few are statistically different from zero. However, county debt limits join municipal debt limits as negatively associated with special district utilization. Beyond this one finding related to debt limits, there is little evidence that local autonomy influences the share of special district spending.

The results for the control variables are generally not statistically significant. This is unsurprising given the assumption that counties along a state border are similar to each other. However, there are two interesting results worthy of highlighting. First, in both contiguous border county-pair sample results, greater personal income per capita relative to a cross border neighbor is associated with greater utilization of special districts. This is a result echoed in Goodman and Leland (2017). Given the durability of the result across the models presented here as well in more traditional approaches, it begs the question of whether preference for specialized governance is a normal good that is an increasing function of income. There are numerous implications to such a conclusion and warrants more research. Second, consistent in all four models is a large and significant effect for the usage of towns. In many states, towns are a more limited form of general purpose government without many of the powers of municipalities (Abress 2000). These results would suggest that relative to states without the usage of towns, counties in states with towns have a much higher utilization of special districts. Because towns are typically limited in their service delivery scope, overlapping special districts provide a means to increase service provision in these areas.

\section{Discussion \& Conclusion}

The intent of this analysis is to examine the relationship between local autonomy and special districts through a different lens. I utilize a different dependent variable than is typical in the literature and utilize a different estimation strategy to force a more quasi-experimental focus to the analysis. Overall, the findings suggest little to no systematic effect of local autonomy on the special district share of local government public spending. Through triangulation of results, this analysis gives more weight to the prior findings of no relationship between local autonomy and special district creation/usage (Berry 2009; Billings and Carroll 2012; Lewis 2000; Shi 2017; Carr 2006). From a policy perspective, the concern about reductions in local autonomy and their potential to shift public services to special districts is important. If this is the case, the intended effect of the reductions would not be realized (restricting the growth of local government); counter to the intentions of state legislatures. This analysis suggests that very little of such shifting is occurring lessening the concern about circumvention of state law. An important caveat to this conclusion is the measures of local autonomy utilized are blunt, lacking the nuance that is often present in grants of autonomy from states. This is due to data availability and future research should seek to improve the quality of local autonomy data.

This analysis presents a number of unique contributions to the literature. First, the utilization of the special district share of local spending as the dependent variable is something rarely found in the literature. The closest approximation is that of Foster (1997) who utilizes share of local spending in a limited context to determine if there is an upward bias in spending associated with special district usage. The construction of the dependent variable is the same, but used for an 
entirely different purpose. Using the share of spending rather than counts of districts solves one important problem plaguing the special district literature; that of over-counting defunct special districts. Second, this analysis moves away from the traditional fixed effects approach to examining the influence of changes in local autonomy on special districts. By exploiting policy discontinuities at state borders, a quasi-experiment is constructed. By examining differences in county pairs that are alike in many more ways than the randomly chosen county, a stronger hypothesis test is conducted. Finally, the long panel of this analysis is not unique among the literature, but is uncommon (Billings and Carroll 2012; Farmer 2010; McCabe 2000; Shi 2017). This long panel allows for many more changes in local autonomy than one or two period analyses. Given how slowly local autonomy changes, the extra time is important in the identification strategy. Taken together, this analysis is a large change in the literature. Finally, this analysis can be seen as exploring the effects of second order devolution (state to local) on third order devolution (local to other) (Bowman and Kearney 2011). Much work has been done examining this relationship between changes in state rules and its effects on local service delivery, ${ }_{13}^{13}$ but little has been motivated in this context. Bowman and Kearney $(2011,579)$ suggest additional work "to bring TOD into the federalism equation" and this analysis can be seen as a preliminary step.

More broadly, specialized governance has other important influences worth mentioning. As Hammond and Tosun (2011) find, local governance arrangements can have important impacts on the economic growth of local areas. Among urban counties, higher utilization of special districts is associated with increased population and employment growth. Similarly, there is much evidence to suggest that increasing vertical local governance structures (of which special districts are one of a few) increase public spending and taxes to inefficiently high levels (Berry 2008; Goodman 2015). These two results suggest a tradeoff in increased utilization of special districts. The growth in special districts is unlikely to stop anytime soon, potentially exacerbating these two competing effects; however, this analysis suggests that changes in state law surrounding local autonomy is not a driver of such growth.

\section{References}

Abress, Monica Dwyer. 2000. Quietly at Work: Township Government in America. North Branch, MN: Specialty Press.

Advisory Commission on Intergovernmental Relations. 1981. Measuring Local Discretionary Authority. Washington, D.C.: Government Printing Office.

- . 1993. State Laws Governing Local Government Structure and Administration. Washington D.C.: Government Printing Office.

- . 1995. Tax and Expenditure Limitations on Local Governments. Bloomington, IN: Center for Urban Policy / the Environment, Indiana University.

Bauroth, Nicholas. 2005. "The Influence of Elections on Special District Revenue Policies: Special Democracies or Automatons of the State." State \& Local Government Review 37 (3): 193-205.

— . 2015. "Hide In Plain Sight: The Uneven Proliferation of Special Districts Across the United States by Size and Function." Public Administration Quarterly 39 (2): 295-324.

\footnotetext{
${ }^{13}$ Special districts reliance is one of many ways local governments can cope with changes in state rules. Inter-local agreements (Krueger and Bernick 2010) and outsourcing (Krueger, Walker, and Bernick 2011) have been recently examined.
} 
Berry, Christopher R. 2008. "Piling On: Multilevel Government and the Fiscal Common-Pool." American Journal of Political Science 52 (4): 802-820.

— . 2009. Imperfect Union: Representation and Taxation in Multilevel Governments. Cambridge: Cambridge University Press.

Billings, Stephen B., and Deborah A. Carroll. 2012. "Debrucing the Link Between Tax and Expenditure Limits and Special District Governments." Growth and Change 43 (2): 273-303.

Bollens, John C. 1957. Special District Governments in the United States. Berkeley and Los Angeles: University of California Press.

Bollens, Scott. 1986. "Examining the Link between State Policy and the Creation of Local Special Districts." State $\mathcal{E}$ Local Government Review 18 (3): 117-124.

Bowler, Shaun, and Todd Donovan. 2004. "Evolution in state governance structures: Unintended consequences of state tax and expenditure limitations." Political Research Quarterly 57 (2): 189196.

Bowman, Ann O'M. 2017. "The State-Local Government(s) Conundrum: Power and Design." The Journal of Politics 79 (4): 1119-1129.

Bowman, Ann O'M, and Richard C. Kearney. 2011. "Second-Order Devolution: Data and Doubt." Publius: The Journal of Federalism 41 (4): 563-585.

Briffault, Richard. 1993. "Who Rules at Home? One Person/One Vote and Local Governments." University of Chicago Law Review 60 (2): 339-424.

Bunch, Beverly S. 1991. "The Effect of Constitutional Debt Limits on State Government Use of Public Authorities." Public Choice 68 (1): 57-69.

Burns, Nancy. 1994. The Formation of American Local Governments: Private Values in Public Institutions. New York, NY: Oxford University Press.

Carr, Jered B. 2006. "Local Government Autonomy and State Reliance on Special District Governments: A Reassessment." Political Research Quarterly 59 (3): 481-492.

Carr, Jered B., and Jayce Farmer. 2011. "Contingent Effects of Municipal and County TELs on Special District Usage in the United States." Publius: The Journal of Federalism 41 (4): 709-733.

Dube, Arindajit, T. William Lester, and Michael Reich. 2010. “Minimum Wage Effects Across State Borders: Estimates Using Contiguous Counties." Review of Economics and Statistics 92 (4): 945964.

Farmer, Jayce. 2010. “Factors Influencing Special Purpose Service Delivery among Counties." Public Performance E Management Review 33 (4): 535-554.

Farnham, Paul G. 1985. "Re-examining local debt limits: A disaggregated analysis." Southern Economic Journal 51 (4): 1186-1201.

Faulk, Dagney, and Larita Killian. 2017. "Special Districts and Local Government Debt: An Analysis of "Old Northwest Territory" States." Public Budgeting \& Finance 37 (1): 112-134.

Foster, Kathryn A. 1997. The Political Economy of Special-Purpose Government. Washington D.C.: Georgetown University Press.

Frant, Howard. 1997. "Reconsidering the Determinants of Public Authority Use." Journal of Public Administration Research and Theory 7 (4): 571-590. 
Goodman, Christopher B. 2015. "Local Government Fragmentation and the Local Public Sector: A Panel Data Analysis." Public Finance Review 43 (1): 82-107.

Goodman, Christopher B., and Suzanne M. Leland. 2017. "Do Cities and Counties Attempt to Circumvent Changes in Their Autonomy by Creating Special Districts?" Working paper.

Hammond, George W., and Mehmet S. Tosun. 2011. "The impact of local decentralization on economic growth: Evidence from U.S. counties." Journal of Regional Science 51 (1): 47-64.

Hudson, Kari. 1996. "Special District Governments: Examining the Questions of Control." American City \& County ().

Joyce, Phillip G., and Daniel R. Mullins. 1991. “The Changing Fiscal Structure of State and Local Public Sector: The Impact of Tax and Expenditure Limitations." Public Administration Review 51 (3): 240-253.

Krane, Dale, Platon N. Rigos, and Melvin B. Hill. 2001. Home Rule in America: A Fifty-State Handbook. Washington D.C.: CQ Press.

Krueger, Skip, and Ethan M. Bernick. 2010. "State Rules and Local Governance Choices." Publius: The Journal of Federalism 40 (4): 697-718.

Krueger, Skip, Robert W. Walker, and Ethan M. Bernick. 2011. "The intergovernmental context of alternative service delivery choices." Publius: The Journal of Federalism 41 (4): 686-708.

Leigland, James. 1990a. "In Defense of a Preoccupation with Numbers: A Response." Political Research Quarterly 43 (2): 385-386.

— . 1990b. “The Census Bureau's Role in Research on Special Districts: A Critique." Western Political Quarterly 43 (2): 367-380.

Lewis, Paul G. 2000. “The Durability of Local Government Structure: Evidence from California." State E Local Government Review 32 (1): 34-48.

Little Hoover Commission. 2000. Special Districts: Relics of the Past or Resources for the Future. Sacramento: Little Hoover Commission.

MacManus, Susan A. 1981. "Special District Governments: A Note on Their Use As Property Tax Relief Mechanisms in the 1970s." The Journal of Politics 43 (4): 1207-1214.

Maynard, Melissa. 2013. "Cash-Strapped Governments Turn to Special Districts." Pew Charitable Trusts ().

McCabe, Barbara C. 2000. "Special-District formation among the states." State $\mathcal{E}$ Local Government Review 32 (2): 121-131.

McEachern, William A. 1978. "Collective Decision Rules and Local Debt Choice: A Test of the Median-Voter Hypothesis." National Tax Journal 31 (2): 129-136.

Mullins, Daniel R., and Phillip G. Joyce. 1996. "Tax and Expenditure Limitations and State and Local Fiscal Structure: An Empirical Assessment." Public Budgeting \& Finance 16 (1): 75-101.

Mullins, Daniel R., and Bruce A. Wallin. 2004. “Tax and Expenditure Limitations: Introduction and Overview." Public Budgeting and Finance 24 (4): 2-15. ISSN: 02751100.

Nelson, Michael A. 1990. "Decentralization of the Subnational Public Sector: An Empirical Analysis of the Determinants of Local Government Structure in Metropolitan Areas in the US." Southern Economic Journal 57 (2): 443-457. 
Pogue, Thomas F. 1970. "The Effect of Debt Limits: Some New Evidence." National Tax Journal 23 (1): $36-49$.

Sacks, Seymour. 1990. "“The Census Bureau's Role in Research on Special Districts: A Critique”: A Necessary Rejoinder." Western Political Quarterly 43 (2): 381-383.

Sbragia, Alberta M. 1996. Debt Wish: Entrepreneurial Cities, U.S. Federalism, and Economic Development. Pittsburgh: University of Pittsburgh Press.

Shi, Yu. 2017. "The Rise of Specialized Governance in American Federalism: Testing Links Between Local Government Autonomy and Formation of Special District Governments." Publius: The Journal of Federalism 47 (1): 99-130.

Tiebout, Charles M. 1956. "A Pure Theory of Local Expenditures." Journal of Political Economy 64 (5): 416-424.

U.S. Census Bureau. 2013. 2012 Census of Governments, Individual State Descriptions. Washington, D.C.: Government Printing Office.

Yusef, Juita-Elena (Wie), et al. 2013. "State Fiscal Constraints on Local Government Borrowing: Effects on Scale and Cost." In Handbook of Local Governemnt Fiscal Health, ed. by Helisse Levine, Jonathan B. Justice, and Eric Scorsone. Burlington, MA: Jones / Bartlett, Inc. 